\title{
Spatial and seasonal variations of leaf area index (LAI) in subtropical secondary forests related to floristic composition and stand characters
}

\author{
Wenjuan Zhu ${ }^{1,2}$, Wenhua Xiang ${ }^{1,2,3}$, Qiong Pan ${ }^{4,1}$, Yelin Zeng ${ }^{1}$, Shuai Ouyang ${ }^{1,2,3}$, Pifeng Lei ${ }^{1,2,3}$, \\ Xiangwen Deng ${ }^{1,2,3}$, Xi Fang ${ }^{1,2,3}$, and Changhui Peng ${ }^{5,1}$ \\ ${ }^{1}$ Faculty of Life Science and Technology, Central South University of Forestry and Technology, Changsha 410004, \\ Hunan Province, China \\ ${ }^{2}$ Huitong National Field Station for Scientific Observation and Research of Chinese Fir Plantation Ecosystem in \\ Hunan Province, Huitong 438107, China \\ ${ }^{3}$ National Engineering Laboratory of Applied Technology for Forestry \& Ecology in Southern China, Changsha 410004, \\ China \\ ${ }^{4}$ Changsha Environmental Protection College, Changsha 410004, China \\ ${ }^{5}$ Institute of Environment Sciences, Department of Biological Sciences, University of Quebec at Montreal, Montreal, \\ QCH3C 3P8, Canada
}

Correspondence to: Wenhua Xiang (xiangwh2005@163.com)

Received: 6 January 2016 - Published in Biogeosciences Discuss.: 12 February 2016

Revised: 1 June 2016 - Accepted: 8 June 2016 - Published: 1 July 2016

\begin{abstract}
Leaf area index (LAI) is an important parameter related to carbon, water, and energy exchange between canopy and atmosphere and is widely applied in process models that simulate production and hydrological cycles in forest ecosystems. However, fine-scale spatial heterogeneity of LAI and its controlling factors have yet to be fully understood in Chinese subtropical forests. We used hemispherical photography to measure LAI values in three subtropical forests (Pinus massoniana-Lithocarpus glaber coniferous and evergreen broadleaved mixed forests, Choerospondias axillaris deciduous broadleaved forests, and L. glaberCyclobalanopsis glauca evergreen broadleaved forests) from April 2014 to January 2015. Spatial heterogeneity of LAI and its controlling factors were analysed using geostatistical methods and the generalised additive models (GAMs) respectively. Our results showed that LAI values differed greatly in the three forests and their seasonal variations were consistent with plant phenology. LAI values exhibited strong spatial autocorrelation for the three forests measured in January and for the L. glaber-C. glauca forest in April, July, and October. Obvious patch distribution pattern of LAI values occurred in three forests during the non-growing pe-
\end{abstract}

riod and this pattern gradually dwindled in the growing season. Stem number, crown coverage, proportion of evergreen conifer species on basal area basis, proportion of deciduous species on basal area basis, and forest types affected the spatial variations in LAI values in January, while stem number and proportion of deciduous species on basal area basis affected the spatial variations in LAI values in July. Floristic composition, spatial heterogeneity, and seasonal variations should be considered for sampling strategy in indirect LAI measurement and application of LAI to simulate functional processes in subtropical forests.

\section{Introduction}

Many fundamental ecological processes in forest ecosystems, such as carbon (C) flux as well as water and energy exchanges, take place between the canopy layer and atmosphere (GCOS, 2006; Brut et al., 2009; Alonzo et al., 2015; Liu et al., 2015b). At a finer scale, leaves within the canopy are the primary organ to perform a series of physiological activities (i.e. photosynthesis, respiration, and evapotranspi- 
ration) (Aragão et al., 2005) and physical reactions (i.e. rainfall and radiation interception) (Aston, 1979; Smith, 1981; Crockford and Richardson, 2000). Therefore, the amount of leaves in a forest is the determinant of above-ground ecological processes and ecosystem functions. Leaf area index (LAI), defined as total one-sided leaf area per unit ground surface area (Biudes et al., 2014), is a widely used parameter (Kross et al., 2015) to quantitatively describe the vegetation canopy structure (Woodgate et al., 2015), to simulate ecological process models (Brooks et al., 2006; Sprintsin et al., 2007; Facchi et al., 2010; Gonsamo and Chen, 2014), and to reveal tree growth and productivity in forests at stand scale and landscape level (Lee et al., 2004; Liu et al., 2015b). In addition, LAI is listed as one of the essential variables for observation of global climate (Mason et al., 2003; Manninen et al., 2009) and for remote sensing data validation (Asner et al., 2003; Clark et al., 2008). Thus, accurate estimates of LAI values are important to understand ecological processes in forest ecosystems.

At present, various direct and indirect methods have been developed to measure LAI in forests. Direct estimation methods including leaf harvest (Clark et al., 2008), allometric equations, and litter collection (Ryu et al., 2010; Liu et al., 2015a) are recognised as the most accurate. However, leaf harvest and allometric equations methods need timeconsuming, labour-intensive, and destructive sampling processes, while litter collection is more feasible for temperate deciduous forests. Obviously, the direct methods are less applicable to large-scale and long-term LAI monitoring (Bequet et al., 2012; Biudes et al., 2014). Indirect methods include using a plant canopy analyser (Licor LAI-2000), hemispherical or fisheye photography (Macfarlane et al., 2007), and remote sensing (Biudes et al., 2014). The indirect methods retrieve LAI value from light transmittance through canopies or from canopy image analysis. For large-scale LAI estimates, remote sensing is the most effective method but requires validation with ground-based LAI data. LAI estimates on the ground at small scales are still a challenge due to the problems of sampling strategies associated with accepted level of accuracy, time, and cost considerations (Richardson et al., 2009). Hemispherical photography is a relatively simple and easily operated method among many indirect methods to retrieve LAI value at small scales (Demarez et al., 2008). Correction of the effects of woody materials, clumping and zenith angels or exposure is critical to improve the accuracy of LAI estimation (Liu et al., 2015b). Analysis software development and portable and timely characteristics allow hemispherical photography to measure spatial heterogeneity and seasonal variations of LAI in forests.

Forest canopy structure is highly complex so LAI values show great temporal and spatial variations at scales ranging from stand to global scale. For example, LAI values in the 7.9 ha plot of an old humid temperate forest tended to increase spatially as elevation increased and showed a temporal variation with plant phenology (Naithani et al., 2013).
The spatial patterns of LAI values at stand scale were significantly influenced by spatial distribution of tree species, which was dependent on topography and soil types (Naithani et al., 2013). The coefficient of variation (CV) in LAI decreased as the scale increased and LAI values did not have any relationship to biome type and climate patterns, but they were influenced by land use and land cover, terrain features, and soil properties at stand scale (Aragão et al., 2005). The $\mathrm{CV}$ of LAI of three species (i.e. beech, oak, and pine) had different degrees of spatial variation in a 1 ha plot at stand level (Bequet et al., 2012). LAI values in sagebrush displayed strong spatial patterns with time after disturbance and increased with stand age and total plant cover (Ewers and Pendall, 2007). The LAI values derived from MODIS data (Myneni et al., 2002; Huang et al., 2008) revealed strong spatial variations at global scale, which were correlated with latitude (Tian et al., 2004). At the global scale, temperature is the limiting factor for LAI under cool conditions while water plays a predominant role under other conditions, and this pattern differed among plant functional types (Iio et al., 2014). The factors that govern the spatial variations in LAI values at stand level include forest types, stand structure (Bequet et al., 2012), climate (Shao and Zeng, 2011), topography, soil moisture condition (Breshears and Barnes, 1999), and human disturbance and management activities (Huang and Ji, 2010). Although effects of topography, soil properties (Aragão et al., 2005; Naithani et al., 2013), and stand characters (Bequet et al., 2012; Yao et al., 2015) on LAI values have been investigated in detail, the effect of forest type, stand structural diversity, and stand structure on spatial heterogeneity and seasonal variations of LAI has yet to be fully understood.

Chinese subtropical forests contain a diversity of tree species with complex canopy structure that mostly grow on heterogeneous topography and soil conditions. As a result, LAI in subtropical forests may exhibit great spatial and seasonal variations, which is worthy of further investigation. However, LAI data of subtropical forests are relatively deficient in the global database (see Asner et al., 2003). In this study, we selected three different forests: Pinus massoniana-Lithocarpus glaber coniferous and evergreen broadleaved mixed forests, Choerospondias axillaris deciduous broadleaved forests, and L. glaber-Cyclobalanopsis glauca evergreen broadleaved forests, which were measured by using hemispherical photography to measure LAI values. Spatial heterogeneity of LAI was investigated through geostatistical analysis, and generalised additive models (GAMs) were used to examine how stand structural diversity and stand characters affect LAI variations in the three forests. Specifically, the objectives of this study were (1) to examine differences and seasonal variations in LAI among three forests in subtropical China; (2) to analyse spatial heterogeneity of LAI values within a specific forest; and (3) to identify how forest types, stand structural diversity, and stand characters control the spatial heterogeneity and seasonal variations of LAI values in three forests. 


\section{Materials and methods}

\subsection{Study site description}

The study was carried out at Dashanchong Forest Farm (latitude $28^{\circ} 23^{\prime} 58^{\prime \prime}-28^{\circ} 24^{\prime} 58^{\prime \prime} \mathrm{N}$, longitude $113^{\circ} 17^{\prime} 46^{\prime \prime}-$ $113^{\circ} 19^{\prime} 08^{\prime \prime}$ E), Changsha County, Hunan Province, China. The farm experiences a humid mid-subtropical monsoon climate. Mean annual air temperature was $16.5^{\circ} \mathrm{C}$, with a mean monthly minimum temperature of $-11^{\circ} \mathrm{C}$ in January and maximum temperature of $40^{\circ} \mathrm{C}$ in July. Mean annual precipitation ranged from 1412 to $1559 \mathrm{~mm}$, mostly occurring between April and August. The topography is characterized by a typical low hilly landscape with an altitude between 55 and $260 \mathrm{~m}$ above sea level. Soil type is designated as welldrained clay loam red soil developed on slate and shale rock, classified as Alliti-Udic Ferrosols, corresponding to Acrisol in the World Reference Base for Soil Resource (IUSS Working Group WRB, 2006). Evergreen broadleaved forest is the climax vegetation of the region. As a result of human disturbance and management activities, the farm has no primary forest, and possesses a range of secondary forests in different stages of succession (based on species composition) dominated by different tree species, including (1) early-stage $P$. massoniana-L. glaber coniferous and evergreen broadleaved mixed forests dominated by the shade-intolerant coniferous species typical of early succession, (2) middle-stage $C$. $a x$ illaris deciduous broadleaved forests dominated by shadeintolerant deciduous broadleaf species, and (3) late-stage $L$. glaber-C. glauca evergreen broadleaved forests dominated by the shade-tolerant evergreen broadleaved species commonly observed in the late stage of succession in this farm (Xiang et al., 2015; Ouyang et al., 2016).

\subsection{Determination of stand characteristics}

We established a permanent plot for each of three forests (i.e. $90 \mathrm{~m} \times 190 \mathrm{~m}$ irregular plot for P. massoniana-L. glaber mixed forests, $100 \mathrm{~m} \times 100 \mathrm{~m}$ plot for $C$. axillaris deciduous forests, and $100 \mathrm{~m} \times 100 \mathrm{~m}$ plot for $L$. glaber-C. glauca evergreen broadleaved forests). Each plot was divided into $10 \mathrm{~m} \times 10 \mathrm{~m}$ subplots, where tree species, diameter at breast height (DBH, in centimetres), tree height ( $H$, in metres), height under the lowest live branch (in metres) and crown width (in metres) were measured for the individual stem with DBH larger than $1 \mathrm{~cm}$. Stand characteristics for the trees with $\mathrm{DBH}>4 \mathrm{~cm}$ of the three forests are presented in Table S1 in the Supplement.

To identify the factors that control spatial heterogeneity of LAI values in the forests, we selected individual trees with $H$ larger than average height of each stand (see Table S1) and calculated their stem number, average $\mathrm{DBH}, H$, total basal area at breast height (BA), crown width, crown coverage (calculated from crown diameter measured for individual trees within a stand), tree species diversity, tree size diversity, the proportion of BA of three functional groups (coniferous, deciduous, and evergreen broadleaved species) to total stand BA within a subplot. Tree species diversity (biodiversity index, BDI) was determined using the Shannon-Wiener index as follows:

$\mathrm{BDI}=-\sum P_{i} \ln P_{i}$,

where $P_{i}$ is important value of $i$ th species and is calculated by dividing the sum of relative abundance degree and relative dominance degree of $i$ th species within a subplot by two.

Based on the Shannon-Wiener index, $2 \mathrm{~cm}$ was used for the DBH class, so tree size diversity $(H)$ was determined using the formula of Lei et al. (2009):

$H=-\sum P_{i} \ln P_{i}$,

where $P_{i}$ is the proportion of basal area for the $i$ th diameter class.

\subsection{Sampling design for LAI measurement}

At the centre of each subplot of the three forests, hemispherical photographs were taken using a LAI measuring instrument (SY-S01A, Shiya Scientific and Technical Cooperation, Hebei, China) throughout four measurement seasons, i.e. in April (spring), July (summer) and October (autumn) in 2014, and January (winter) in 2015. The operation was carried out below canopy with the fisheye lens (Pentax TS2V114E, Japan) $1.0 \mathrm{~m}$ above the ground (Manninen et al., 2009 ) with a viewing angle of $180^{\circ}$. The picture exposure is automatic exposure set by the manufacturer, and we took the photographs $(768 \times 494$ pixels, BMP) in the morning, at dusk, or when cloudy in order to minimise influence of direct sunshine (Rich, 1990; Bequet et al., 2012). The images were processed and effective LAI values $\left(L_{\mathrm{e}}\right)$ were recorded using plant canopy analysis software developed by the manufacturer, for which appropriate pixel classification (thresholding) was chosen $(752(H) \times 494(V)$, where $V$ is vertical resolution), viewing angle was considered $\left(150^{\circ}\right)$, and the hemispherical photography was divided into five rings to obtain results. To obtain accurate LAI $(L)$, the correction was made to $L_{\mathrm{e}}$ based on previous theory (Chen, 1996):

$L=\frac{(1-\alpha) L_{\mathrm{e}} \gamma_{\mathrm{E}}}{\Omega_{\mathrm{E}}}$,

where $\alpha$ is the ratio of woody to total area and reflects the contribution of woody materials to $L_{\mathrm{e}}$, and $\Omega_{\mathrm{E}}$ is the clumping index that quantifies the effect of foliage clumping beyond shoots level. In the method getting accurate $\Omega_{\mathrm{E}}$ values, the hemispherical photography was divided into 10 sectors. $\gamma_{\mathrm{E}}$ is the needle-to-shoot-area ratio and quantifies the effect of foliage clumping within shoots.

Photoshop software (Adobe Photoshop CS5, Adobe Systems Incorporated, North America) was used to calculate $\alpha$. After total pixel number of $L_{\mathrm{e}}$ image was determined, in the 
Photoshop software, we used the clone stamp tool to select the image of the woody materials (e.g. stems) and excluded the pixels, leaving only leaves on the photos, recorded as LAI of leaves $\left(\mathrm{LAI}_{\text {leaf }}\right)$. The value of $\alpha$ was calculated accordingly:

$\alpha=\left(L_{\mathrm{e}}-\mathrm{LAI}_{\text {leaf }}\right) / L_{\mathrm{e}}$.

The logarithm averaging method proposed by Lang and Xiang (1986) was applied to calculate $\Omega_{\mathrm{E}}$ :

$\Omega(\theta)=\frac{\ln [P(\bar{\theta})]}{\ln [P(\bar{\theta})]}=\frac{n \ln [P(\bar{\theta})]}{\sum_{k=1}^{n} \ln \left(P_{k}(\theta)\right]}$,

where $P(\theta)$ is the average gap fraction (expressed without the bar in the text), $\ln [P(\theta)]$ is the logarithm average of the gap fraction, and $P_{k}(\theta)$ is the gap fraction of segment $k$. For deciduous and evergreen broadleaved species, $\gamma_{E}=1.0$; for coniferous species $\gamma_{\mathrm{E}}$ is always $>1.0$, but we ignored the effect of needle to shoot area on LAI in this study.

\subsection{Data analysis}

The minimum, maximum, mean value, standard deviation, and CV were calculated for the LAI data measured in 100 plots within each forest. Two-way analysis of variance (ANOVA) was used to detect effect of forest type and measurement season on LAI value. The LAI data in the three forests were tested for normal distribution using the $\mathrm{K}-\mathrm{S}$ test $(P<0.05)$. We followed Chiang et al. $(2003)$ in regarding LAI values as normal when they fell within the mean value \pm 3 standard deviations. Otherwise, the LAI values were regarded as outliers and replaced with the maximum or the minimum of normal values. Because the geostatistical analysis requires that the data meet normal distribution, the transformation was applied when the data did not meet normal distribution (Dai et al., 2014). Most values required natural logarithm transformation to meet assumptions of normality. The exception is for L. glaber-C. glauca in April and in November, which were ARTAN-transformed.

To investigate spatial heterogeneity of LAI values over four seasons measured in the three forests, the semivariance function was calculated as follows:

$\gamma(h)=\frac{1}{2 N(h)} \sum_{i=1}^{N(h)}\left[Z\left(x_{i}\right)-Z\left(x_{i}+h\right)\right]^{2}$,

where $\gamma(h)$ is the semivariance value of lag distance $h, N(h)$ is the number of pair data for lag distance $h$, and $Z\left(x_{i}\right)$ and $Z\left(x_{i}+h\right)$ represent LAI values at coordinate $x_{i}$ and $\left(x_{i}+h\right)$ (Rossi et al., 1992). Based on the semivariogram plotting $\gamma(h)$ values against $h$ variable, the appropriate models were fitted and we obtained the values of nugget $\left(C_{0}\right)$, sill $\left(C_{0}+C\right)$, range $\left(A_{0}\right)$ (Ewers and Pendall, 2007), and the ratio $\left[C /\left(C_{0}+C\right)\right]$ that reflected the degree of spatial autocorrelation of LAI values in a forest. Because spatial autocorrelation and semivariogram theory make unbiased optimal estimation for regional variables in a limited area (Bivand et al.,
2013), the Kriging interpolation method, an unbiased estimation of the regional variables of the sampling points using the structure of the data and semivariogram function, was used to predict unknown LAI values in the forests from the data measured and to produce spatial distribution maps of LAI values for the three forests and four seasons. Compared with other methods, the Kriging method can overcome the difficulty in analysing error of interpolation, does not produce the boundary effect of regression analysis, and estimates the spatial variability distribution of measured parameters. Ordinary Kriging - one of the Kriging methods - is a least-squares method of spatial prediction based on the assumption of an unknown mean. It is the most common type of Kriging in practice (Dai et al., 2014) and is widely used in soil spatial heterogeneity studies (Elbasiouny et al., 2014). In our study, we also used the ordinary Kriging interpolation method to investigate spatial heterogeneity of LAI values.

Because the largest amount of defoliated leaves occurs in January and leaves fully expand in July in subtropical forests, we chose LAI values measured in January and July in three forests as response variables. The explanatory variables include forest types, stand structural diversity (species richness, tree species diversity, and tree size diversity) and stand characters (stem number, average $\mathrm{DBH}, H$, BA, crown width, crown coverage, and the proportion of two functional groups (deciduous and evergreen conifer species) to total stand BA). GAMs are able to analyse complex and nonlinear relationships (Guisan et al., 2002; Austin, 2002; Wood, 2006). Therefore, we used GAMs to examine how the factors affect LAI values. The function of GAMs is the addition of many smooth functions and each smooth function has an explanatory variable. In our study, we chose smooth spline with two splines as the smooth method for GAMs. The variance inflation factor (VIF) - the ratio of the regression coefficient variance for a variable when fit with all variables to that for the variable if fit on its own - was used to test the multi-collinearity of explanatory variables (James et al., 2013). When the VIF of an explanatory variable is between 0 and 10 , the variable was retained to the model; otherwise, we discarded the variable (Shen et al., 2015). The Akaike information criterion (AIC) or generalised cross-validation (GCV) was used to determine whether the model was good or bad (Clark, 2013). The factors selected after the multicollinearity test were used for multi-factor analysis. After all the possible models in multi-factor analysis, we determined the optimal model based on the significant influence of all explanatory variables in the model with the smallest AIC or GCV (Dong et al., 2012). Geostatistical analysis was performed with GS+ software (Gamma Design Software). Statistical analysis and GAMs analysis were operated in R 3.2.1 (R Development Core Team, 2015). The car packages were used to test multi-collinearity and the GAM packages were used to select the optimal model. 


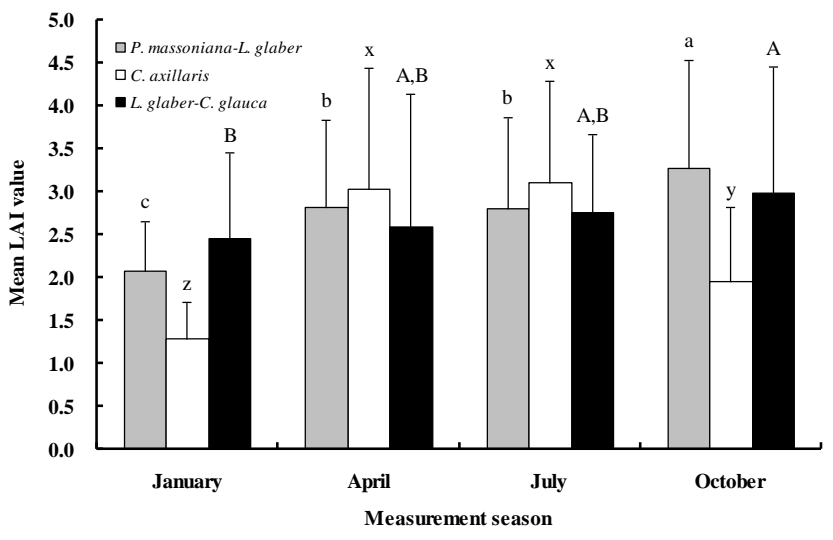

Figure 1. Seasonal variation in mean LAI value (with standard deviation) in P. massoniana-L. glaber, C. axillaris, and L. glaber-C. glauca forests. The different letters by values indicate significant differences $(P<0.05)$ among measurement seasons in a given forest.

\section{Results}

\subsection{Variation in LAI values}

The LAI values varied with forest type and measurement season (Table 1). Generally, LAI differed significantly between measurement seasons $(P<0.001)$, but LAI difference was not significant among forest types $(P>0.05)$. Interactive effects of measurement seasons and forest types on LAI were significant $(P<0.01)$. Among three forests, $\mathrm{LAI}$ in the $P$. massoniana-L. glaber forest had relatively low variation, while LAI in the L. glaber-C. glauca forest had the highest variation. In the P. massoniana-L. glaber forest, LAI showed the largest variation (the highest CVs) in October and the lowest variation (the smallest CVs) in January. In the C. axillaris forest, the largest variation in LAI was found in April and the lowest was found in January. In the L. glaberC. glauca forest, LAI showed the largest variation in April and had the lowest variation in July.

Mean LAI values in the three forests showed different seasonal variation patterns (Fig. 1). The $C$. axillaris forest exhibited a unimodal pattern of seasonal variation, with the maximum mean LAI value $(3.11 \pm 1.18)$ occurring in July and the minimum mean LAI value $(1.28 \pm 0.44)$ in January. In the $P$. massoniana-L. glaber forest and L. glaber-C. glauca forest, the maximum mean LAI values occurred in October and the minimum mean LAI values appeared in January. During the growing season (April and July), the $C$. axillaris forest had the highest mean LAI value and the L. glaber-C. glauca forest had the lowest mean LAI value. During the non-growing season (October and January), the L. glaber-C. glauca forest had the highest mean LAI value in January, while the $P$. massoniana-L. glaber forest had the highest mean LAI value in October, and the $C$. axillaris forest had the lowest mean LAI values.
Mean $\alpha$ values in the three forests showed different seasonal variation patterns (Table 2). The $C$. axillaris forest exhibited a unimodal pattern of seasonal variations in mean $\alpha$ value, with the maximum mean $\alpha$ value occurring in January and the minimum mean $\alpha$ value in July. No obvious seasonal variations were found for the mean $\alpha$ value in the $P$. massoniana-L. glaber forest and in the L. glaber-C. glauca forest. Mean $\Omega_{\mathrm{E}}$ values in the three forests were between 0.84 and 0.92 , but they did not show clear seasonal variations, and the standard deviations were small.

\subsection{Spatial heterogeneity in LAI values}

The semivariogram results for LAI across the three forests during different measurement seasons are summarised in Table 3 . The spatially dependent variance $[C]$ accounted for $88.9-98.4 \%$ of the total variance $\left[C+C_{0}\right]$ for $\mathrm{LAI}$ values measured in January in the three forests and also in April, July, and October in the L. glaber-C. glauca forest. This indicated the strong spatial autocorrelations of LAI values over short distances. These LAI data were best fitted with a Gaussian model or exponential model $\left(r^{2}>0.50\right)$.

Spatial autocorrelation ranges of LAI values differed among forests and measurement seasons (Table 3). In January, the largest spatial autocorrelation range was found in the P. massoniana-L. glaber forest, and the smallest was found in the $C$. axillaris forest. In April, the largest spatial autocorrelation range of LAI was found in the $C$. axillaris forest, and the smallest was found in the P. massoniana-L. glaber forest. In July, the largest spatial autocorrelation range of LAI was in the P. massoniana-L. glaber forest, while the smallest was in the $C$. axillaris forest. In October, the largest spatial autocorrelation range of LAI was in the L. glaber-C. glauca forest, while the smallest was in the P. massonianaL. glaber forest. Seasonal changes of range showed one peak pattern for $C$. axillaris forest and L. glaber-C. glauca forest, where the large range appeared in the growing season (April and July) and the small range appeared in the non-growing season (October and January).

Spatial distribution pattern of LAI values also varied with forest type and measurement season (Fig. 2). For example, LAI values in January across the three forests exhibited obvious patch and heterogeneous spatial distribution. In April and July, less spatial heterogeneity was found for LAI values especially in the P. massoniana-L. glaber forest. In October, heterogeneous and patch spatial distributions of LAI values appeared in the L. glaber-C. glauca forest, and banded spatial distributions of LAI values obviously appeared in the $C$. axillaris forest. 
P. massoniana-L. glaber
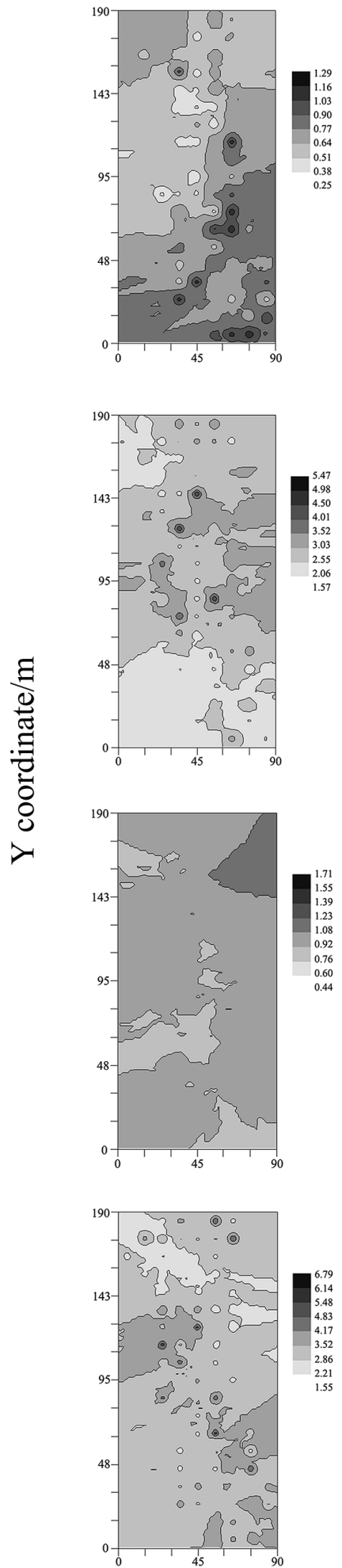

C. axillaris
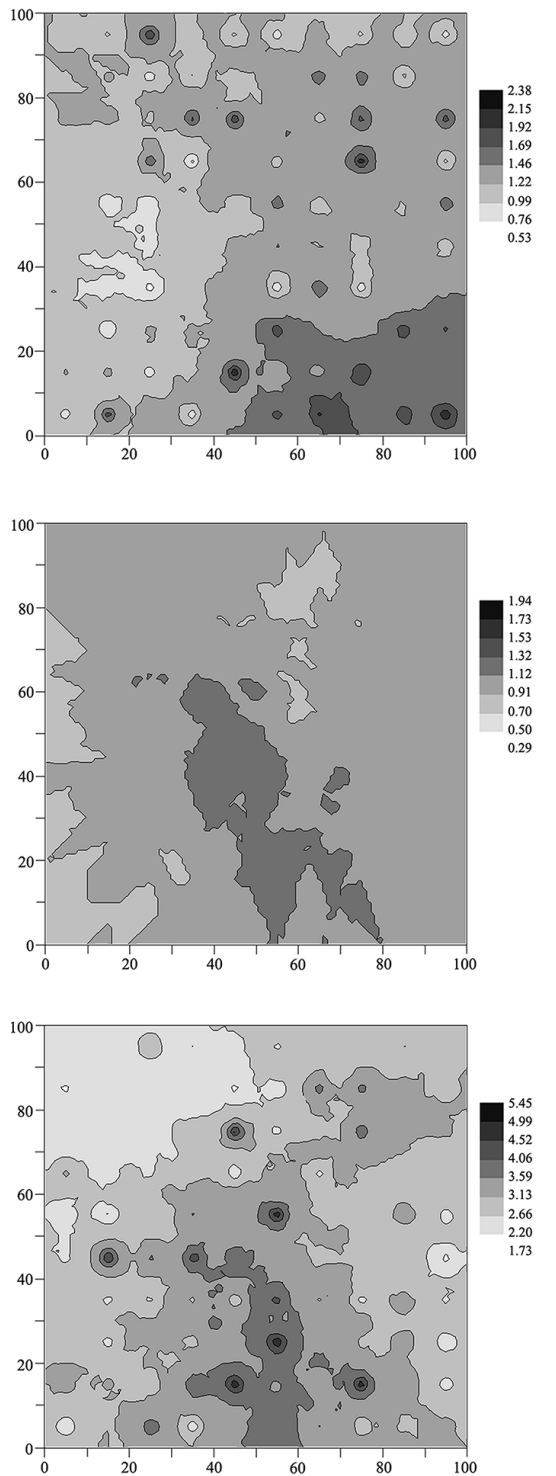

L. glaber-C. glauca
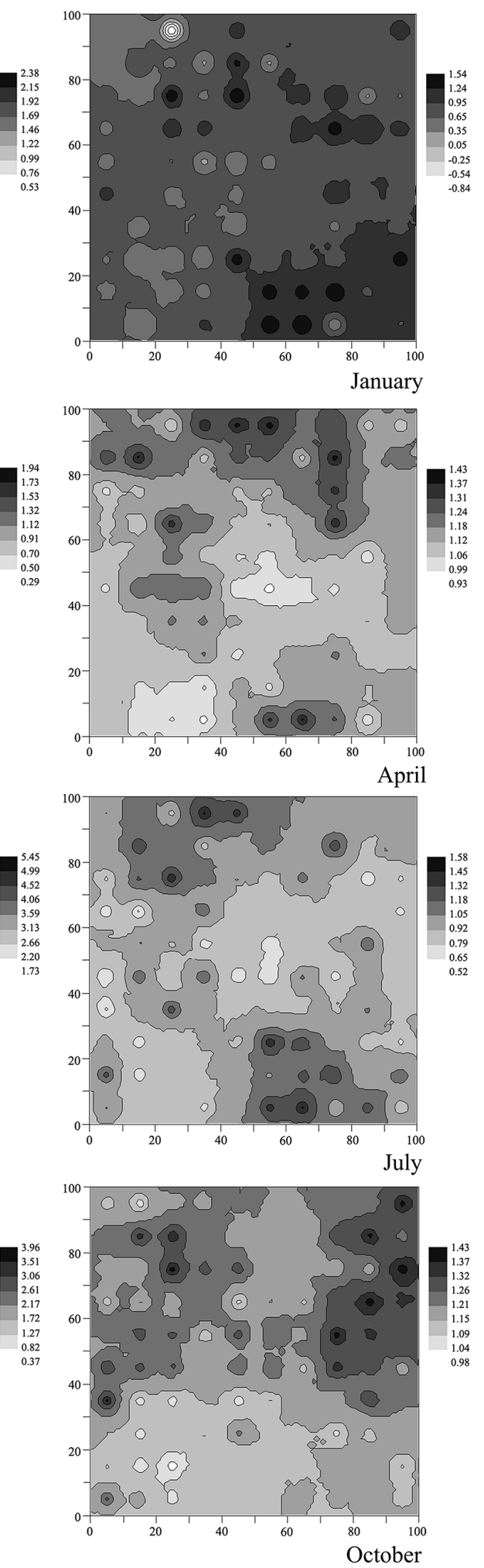

$\mathrm{X}$ coordinate $/ \mathrm{m}$

Figure 2. Spatial heterogeneity map of LAI values interpolated through ordinary Kriging method for P. massoniana-L. glaber, C. axillaris, and L. glaber-C. glauca forests. 
Table 1. Descriptive statistical characteristics of LAI values measured from April 2014 to January 2015 in P. massoniana-L. glaber, C. axillaris, and L. glaber-C. glauca forests $(n=100)$.

\begin{tabular}{|c|c|c|c|c|c|c|}
\hline $\begin{array}{l}\text { Measurement } \\
\text { season }\end{array}$ & $\begin{array}{l}\text { Forest } \\
\text { type }\end{array}$ & $\begin{array}{l}\text { Minimum } \\
\text { value }\end{array}$ & $\begin{array}{r}\text { Maximum } \\
\text { value }\end{array}$ & $\begin{array}{c}\text { Variance } \\
\text { coefficient }(\%)\end{array}$ & $\begin{array}{c}P \text { value of } \\
\mathrm{K}-\mathrm{S} \text { test }\end{array}$ & $\begin{array}{c}\text { Data } \\
\text { transformation }\end{array}$ \\
\hline \multirow[t]{3}{*}{ January } & P. massoniana-L. glaber & 1.29 & 4.03 & 27.5 & 0.021 & 0.275 \\
\hline & C. axillaris & 0.53 & 2.38 & 34.0 & 0.260 & \\
\hline & L. glaber-C. glauca & 0.43 & 6.98 & 40.2 & 0.018 & 0.243 \\
\hline \multirow[t]{3}{*}{ April } & P. massoniana-L. glaber & 1.57 & 7.83 & 36.4 & 0.076 & \\
\hline & C. axillaris & 1.34 & 8.33 & 47.0 & 0.047 & 0.535 \\
\hline & L. glaber-C. glauca & 1.34 & 10.22 & 59.6 & 0.000 & 0.158 \\
\hline \multirow[t]{3}{*}{ July } & P. massoniana-L. glaber & 1.56 & 8.16 & 38.0 & 0.003 & 0.075 \\
\hline & C. axillaris & 1.73 & 8.17 & 37.8 & 0.166 & \\
\hline & L. glaber-C. glauca & 1.68 & 7.58 & 33.1 & 0.010 & 0.170 \\
\hline \multirow[t]{3}{*}{ October } & P. massoniana-L. glaber & 1.55 & 6.79 & 38.3 & 0.321 & \\
\hline & C. axillaris & 0.37 & 6.51 & 44.1 & 0.102 & \\
\hline & L. glaber-C. glauca & 1.49 & 7.88 & 49.3 & 0.000 & 0.212 \\
\hline
\end{tabular}

Table 2. Average woody to total leaf ration $(\alpha)$ and clumping index $\left(\Omega_{\mathrm{E}}\right)$ values in P. massoniana-L. glaber, C. axillaris, and L. glaber-C. glauca forests. Values in parenthesis are the standard deviation of $\alpha$ and $\Omega_{\mathrm{E}}$ values $(n=100)$.

\begin{tabular}{llcccc}
\hline Measurement season & Forest type & \multicolumn{2}{c}{$\begin{array}{c}\text { Mean } \\
\text { value }\end{array}$} & \multicolumn{2}{c}{$\begin{array}{c}\text { Standard } \\
\text { deviation }\end{array}$} \\
\cline { 3 - 6 } & & $\alpha$ & $\Omega_{\mathrm{E}}$ & $\alpha$ & $\Omega_{\mathrm{E}}$ \\
\hline \multirow{2}{*}{ January } & P. massoniana-L. glaber & 0.06 & 0.88 & 0.04 & 0.09 \\
& C. axillaris & 0.15 & 0.92 & 0.09 & 0.08 \\
& L. glaber-C. glauca & 0.07 & 0.87 & 0.09 & 0.09 \\
\hline \multirow{2}{*}{ April } & P. massoniana-L. glaber & 0.08 & 0.87 & 0.05 & 0.09 \\
& C. axillaris & 0.07 & 0.85 & 0.06 & 0.10 \\
& L. glaber-C. glauca & 0.15 & 0.86 & 0.07 & 0.09 \\
\hline \multirow{2}{*}{ July } & P. massoniana-L. glaber & 0.07 & 0.87 & 0.04 & 0.09 \\
& C. axillaris & 0.04 & 0.90 & 0.03 & 0.07 \\
& L. glaber-C. glauca & 0.05 & 0.87 & 0.03 & 0.08 \\
\hline \multirow{2}{*}{ October } & P. massoniana-L. glaber & 0.09 & 0.85 & 0.10 & 0.08 \\
& C. axillaris & 0.14 & 0.87 & 0.14 & 0.10 \\
& L. glaber-C. glauca & 0.09 & 0.84 & 0.08 & 0.09 \\
\hline
\end{tabular}

\subsection{Factors affecting LAI variation}

The multi-collinearity test indicated that the explanatory variables in January and July did not have multi-collinearity. Thus, forest type, species richness, tree species diversity, tree size diversity, stem number, average $\mathrm{DBH}, H$, BA, crown width, crown coverage, and the proportion of two functional groups (deciduous and evergreen conifer species) to total stand BA were included as explanatory variables in multi-factor analysis for LAI values measured in January in the three forests. After comparing all possible models, the best-fitted GAMs for LAI values in January were expressed as LAI $\sim s$ (stem number, 2$)+s$ (crown coverage, 2$)+s$ (PESB, 2) $+s$ (PDSB, 2) + factor (forest types) (Table 4).
For LAI values measured in July, all these factors selected by the multi-collinearity test were included as explanatory variables in multi-factor analysis. The best-fitted GAMs for LAI values in July were expressed as LAI $\sim s$ (stem number, 2) $+s$ (PDSB, 2) (Table 4).

The explanatory variables included in GAMs reflected their effects on or relationship with LAI variations. Given that other variables were fixed, LAI measured in January tended to decrease as stem number increased. LAI showed a positive nonlinear relationship with crown coverage up to $\sim 200 \mathrm{~m}^{2}$ and then decreased with increasing crown coverage. The LAI values tended to increase as the proportion of evergreen conifer species to total stand BA increased and tended to decrease as the proportion of deciduous species to 
Table 3. Semivariogram theoretical models and fitted parameters for LAI values in P. massoniana-L. glaber (90 $\mathrm{m} \times 190 \mathrm{~m}$ irregular shape), C. axillaris $(100 \mathrm{~m} \times 100 \mathrm{~m})$, and L. glaber-C. glauca $(100 \mathrm{~m} \times 100 \mathrm{~m})$ forests.

\begin{tabular}{|c|c|c|c|c|c|c|c|c|}
\hline Measurement season & Forest type & Model & Nugget $\left(C_{0}\right)$ & Sill $\left(C_{0}+C\right)$ & $C /\left(C_{0}+C\right)$ & Range $\left(A_{0}, \mathrm{~m}\right)$ & $r^{2}$ & $\begin{array}{r}\text { Residual sum of } \\
\text { squares (RSS) }\end{array}$ \\
\hline \multirow[t]{3}{*}{ January } & P. massoniana-L. glaber & Exponential & 0.0068 & 0.0614 & 0.889 & 27.00 & 0.607 & $9.762 \times 10^{-5}$ \\
\hline & C. axillaris & Exponential & 0.0030 & 0.1820 & 0.984 & 13.80 & 0.504 & $1.219 \times 10^{-4}$ \\
\hline & L. glaber-C. glauca & Gaussian & 0.0029 & 0.1178 & 0.975 & 15.42 & 0.888 & $3.468 \times 10^{-5}$ \\
\hline \multirow[t]{3}{*}{ April } & P. massoniana-L. glaber & Exponential & 0.1220 & 0.7670 & 0.841 & 17.70 & 0.229 & 0.017 \\
\hline & C. axillaris & Linear & 0.1760 & 0.1760 & 0.000 & 52.96 & 0.189 & $1.762 \times 10^{-4}$ \\
\hline & L. glaber-C. glauca & Exponential & 0.0008 & 0.0152 & 0.951 & 26.40 & 0.978 & $2.290 \times 10^{-7}$ \\
\hline \multirow[t]{3}{*}{ July } & P. massoniana-L. glaber & Linear & 0.0843 & 0.0843 & 0.000 & 92.69 & 0.074 & $1.383 \times 10^{-4}$ \\
\hline & C. axillaris & Exponential & 0.1460 & 0.9340 & 0.844 & 17.70 & 0.258 & 0.017 \\
\hline & L. glaber-C. glauca & Exponential & 0.0065 & 0.0684 & 0.905 & 22.80 & 0.951 & $5.781 \times 10^{-6}$ \\
\hline \multirow[t]{3}{*}{ October } & P. massoniana-L. glaber & Exponential & 0.1620 & 1.6310 & 0.901 & 11.70 & 0.173 & 0.017 \\
\hline & C. axillaris & Spherical & 0.0050 & 0.5830 & 0.991 & 11.90 & 0.000 & $1.870 \times 10^{-3}$ \\
\hline & L. glaber-C. glauca & Exponential & 0.0005 & 0.0125 & 0.960 & 21.90 & 0.894 & $4.444 \times 10^{-7}$ \\
\hline
\end{tabular}

Table 4. Estimated coefficients of the generalised additive models (GAMs) for the factors with effects on LAI values measured in $P$. massoniana-L. glaber, C. axillaris, and L. glaber-C. glauca forests.

\begin{tabular}{llrlcc}
\hline Measurement season & Parameter & $F$ value & $P$ value & $r^{2}$ & AIC \\
\hline January & $s$ (Stem number, 2) & 16.716 & $<0.0001^{* * *}$ & 0.3481 & 655.91 \\
& $s$ (Crown coverage, 2) & 4.545 & $0.034^{*}$ & & \\
& $s$ (PESB, 2) & 26.105 & $<0.0001^{* * *}$ & & \\
& $s$ (PDSB, 2) & 27.281 & $<0.0001^{* * *}$ & & \\
& factor (Forest types) & 39.847 & $<0.0001^{* * *}$ & & \\
\hline July & $s$ (Stem number, 2) & 5.027 & $0.026^{*}$ & 0.040 & 880.93 \\
& $s$ (PDSB, 2) & 7.115 & $0.008^{* *}$ & & \\
\hline
\end{tabular}

The significance of the regressions $(P)$ are *,**, and *** for $P<0.05,0.01$, and 0.001 respectively.

total stand BA increased (Fig. 3). Given that other variables were fixed, LAI measured in July tended to increase as stem number increased up to $\sim 7$ and then decreased at higher values. The effect of the proportion of deciduous species to total stand BA on LAI appeared more complicated, in that LAI increased as the proportion of deciduous species to total stand BA increased up to $\sim 0.7$ and then decreased at higher values (Fig. 4).

\section{Discussion}

\subsection{Seasonal variation in LAI value among forest type}

LAI data in subtropical forests in southern China are lacking compared to other global regions (Asner et al., 2003). This study provided seasonal LAI data in three subtropical forests that consist of contrasting functional types of species. Their mean LAI values varied from $1.28 \pm 0.44$ to $3.28 \pm 1.26$ (Table 1). This result is close to the LAI range (from 1.0 in winter to 4.0 in summer) retrieved by remote sensing techniques from the subtropical area of China from 2000 to 2010 (Liu et al., 2012). Compared with the LAI values estimated from al- lometric equations (Xiang et al., 2016) and specific leaf area values in $40 \mathrm{~m} \times 40 \mathrm{~m}$ plots in this study (5.29-9.19), the LAI values measured by hemispherical photography are low but significantly correlated $\left(r^{2}=0.40\right.$ and $\left.P=0.035\right)$. Previous studies (see Lopes et al., 2015) have proved the underestimation of LAI using hemispherical photography. However, the method is feasible to obtain forest LAI data and to investigate spatial and seasonal variation in such values (Coops et al., 2004; Dovey and Toit, 2006).

The ratio of woody to total area $(\alpha)$ and the clumping index $\left(\Omega_{\mathrm{E}}\right)$ have been recognised as the error sources in LAI measurement by optical methods (Chen et al., 1997; Bréda, 2003; Liu et al., 2015a). So far these two parameters have been measured in northeastern China (Liu et al., 2015a, b), which showed that the $\alpha$ values ranged from $0.04 \pm 0.01$ to $0.69 \pm 0.12$ and $\Omega_{\mathrm{E}}$ values ranged from $0.88 \pm 0.04$ to $0.96 \pm 0.01$. These values were measured in temperate forest in northeastern China and differed from our study (mean $\alpha$ values varied from $0.04 \pm 0.03$ to $0.15 \pm 0.09$ and mean $\Omega_{\mathrm{E}}$ values varied from $0.84 \pm 0.09$ to $0.92 \pm 0.08$ ) (Table 2 ), so they are not suitable for LAI correction in subtropical forests. Also literature on $\alpha$ and $\Omega_{\mathrm{E}}$ values in subtropical forests is scarce. The variations in $\alpha$ are probably due to 

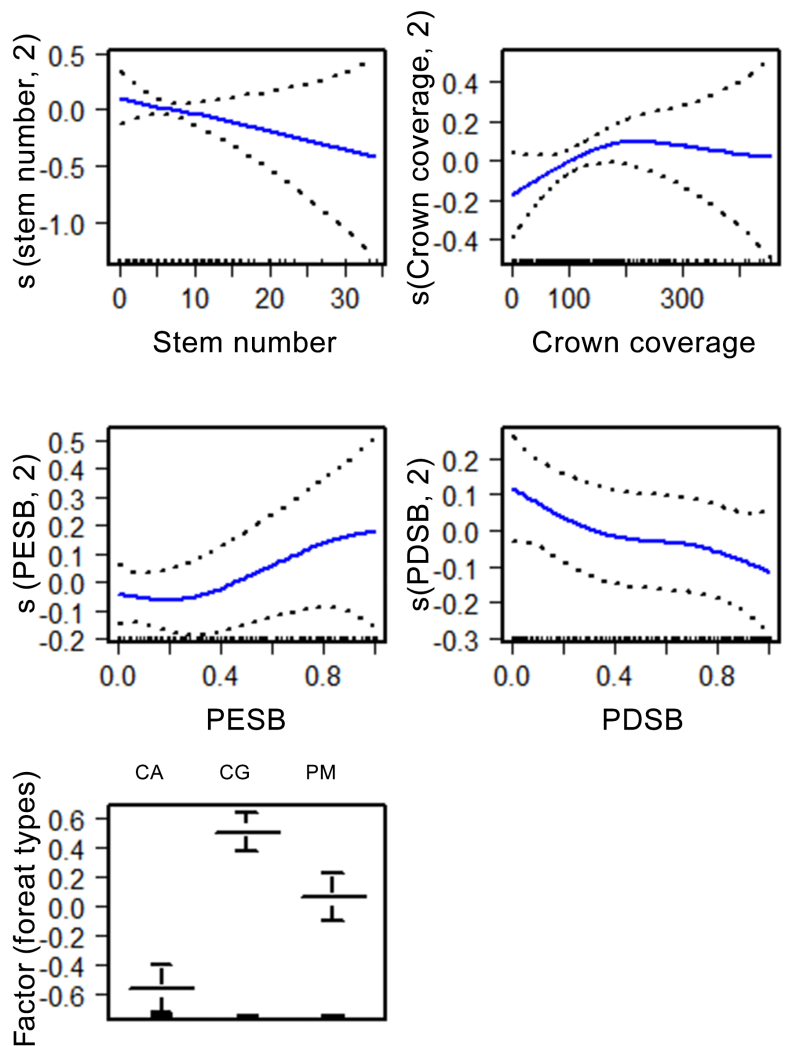

Forest types

Figure 3. Partial effects of stem number, crown coverage $\left(\mathrm{m}^{2}\right)$, the proportion of evergreen conifer species to total stand BA (PESB), the proportion of deciduous species to total stand BA (PDSB), and forest types (calculated for overstorey trees with height larger than average stand height) on the LAI values observed in January in P. massoniana-L. glaber, C. axillaris, and L. glaber-C. glauca forests.

the seasonal variations and spatial heterogeneity of canopy structure in the three forests. In general, the $\alpha$ values are consistent with the amount of leaf litter. Our results showed that the large mean $\alpha$ values occurred in autumn for the $P$. massoniana-L. glaber forest and the C. axillaris forest but in spring and autumn for the L. glaber-C. glauca forest (Table 2). This seasonal change in mean $\alpha$ value in three forests was generally consistent with the amount of leaf litter collected by a litter trap installed in each forest type (Guo et al., 2015). The average $\Omega_{\mathrm{E}}$ value (0.87) in this study was smaller than the values of mixed broadleaved Korean pine forest in northeastern China (Liu et al. 2015b) and this could be attributed to the different region and forests. The values of $\alpha$ and $\Omega_{\mathrm{E}}$ obtained in this study fill the gap of calibration for optical measurement of LAI in subtropical forests.

Mean LAI values differed among the three forests and the differences were significant between the $C$. axillaris forest and the other two forests at a given measurement season. The C. axillaris forest had a relatively high mean LAI value dur-
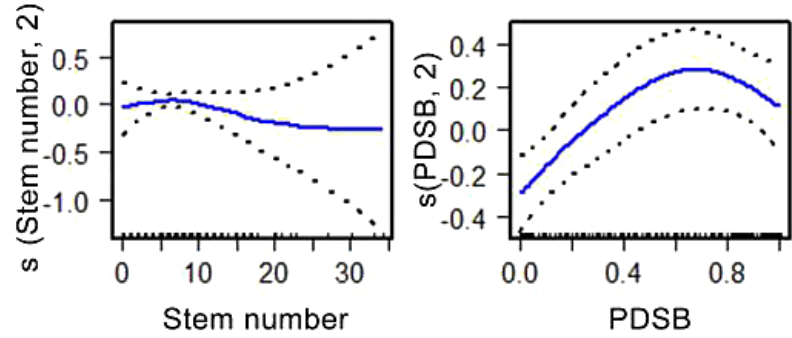

Figure 4. Partial effects of stem number and the proportion of deciduous species to total stand BA (PDSB) (calculated for overstorey trees with height larger than average stand height) on the LAI values observed in July in P. massoniana-L. glaber, C. axillaris, and L. glaber-C. glauca forests.

ing the growing season but changed to the lowest mean LAI value during the non-growing season. The change in mean LAI values in the $C$. axillaris forest was consistent with the study of a deciduous species-dominated forest reported by Naithani et al. (2013). It has been reported that the forests consisting of different plant functional types showed different LAI values (Asner et al., 2003; Iio et al., 2014). The differences and seasonal variations of LAI values in the three forests could be attributed to floristic composition and phenological defoliation patterns of tree species especially the deciduous species. The $C$. axillaris forest consisted of $74.15 \%$ deciduous species, $25.80 \%$ evergreen broadleaved species, and $0.05 \%$ evergreen coniferous species, while the proportions of deciduous species were 10.05 and $25.70 \%$ in the P. massoniana-L. glaber and L. glaber-C. glauca forests respectively. Seasonal growth and defoliation of different functional types of species lead to the change in leaf lifespan and foliage area (Niinemets, 2010) during different seasons related to temperature and water availability, which are responsible for the unimodal pattern of seasonal variation in mean LAI values. This agrees with the results of Liu et al. (2012), where the highest LAI was found in summer (July), followed by autumn (October) and spring (April), and the lowest was found in winter (January).

\subsection{Within-forest spatial heterogeneity and factors controlling LAI}

Semivariograms of LAI values in the three forests were fitted with spherical, Gaussian, exponential, or linear models (Table 3). Based on the fitted models, the degree of spatial autocorrelation could be evaluated. Spatial autocorrelation is weak when the determination coefficient $\left(r^{2}\right)$ of the bestfitted semivariogram model is less than 0.5 (Duffera et al., 2007). The ratio $\left[C /\left(C_{0}+C\right)\right]$ is also used to describe the degree of spatial autocorrelation. A ratio of between 0 and 0.25 indicates a weak spatial autocorrelation, of between 0.26 and 0.75 indicates moderate autocorrelation, and of more than 0.75 indicates strong autocorrelation (Lopez-Granados et al., 
2004). Spatial autocorrelation of LAI in this study varied with forest and measurement season (Table 3). Strong spatial autocorrelation in LAI values at a short range measured in January in all three forests indicated the sampling distance is reasonable for LAI variables within the spatial range (Liu et al., 2008). On the contrary, weak autocorrelation indicated that more samples and smaller sampling intervals should be taken to determine spatial dependency of LAI, such as for LAI measured in April in the P. massoniana-L. glaber forest.

Spatial heterogeneity in LAI values was different for forest type and measurement season. Our study described spatial variations in LAI value by $\mathrm{CV}$ and geostatistical analysis, and the results were largely consistent with each other. In general, the CVs of LAI values in the three forest types (in particular C. axillaris forest) were higher for the period of leaf onset (April) and senescence (October) than for the period of leaf maturity (July) (Table 1). This reflects changes in leaves due to plant phenology and is consistent with the study of Naithani (2013) where LAI became increasingly homogenous from leaf onset to maturity but became more heterogeneous from maturity to senescence. As a result, degree of heterogeneity in LAI value for all three forests tended to dwindle from leaf non-growing season to growing season (Fig. 2).

The complex hydrothermal environment results in complex vertical and horizontal variation in canopy layer and formed unique spatial heterogeneity in LAI values. The effects of stand characters on LAI have been examined and positive and negative effects have been reported (Tobin et al., 2006; Bequet et al., 2012; Yao et al., 2015). In our study, results from GAMs showed that forest types, stand structural diversity, and stand characters affected spatial heterogeneity of LAI values significantly in the three forests. This finding that floristic composition and stand characters affected LAI values measured in July is consistent with the study of Yao et al. (2015); LAI values increased with stem number but when the stem number was larger than 7, LAI values decreased with stem number mainly due to the floristic composition in these study areas. Because July is the period of leaf maturity for deciduous species and leaves fully expand in this season, LAI values tended to increase as ratio of deciduous species increased, but when the ratio was higher than $\sim 0.7$, its negative relationship with LAI probably could be explained by the strong competition among tree species, with diverse species composition and the canopy overlap among tree species (Fig. 4). Our results indicated that LAI values did not exhibit a significant relationship with stand BA, consistent with the findings of Mcdowell (2007); total LAI did not exhibit a clear pattern in relation to stand BA.

Until now, the non-growing season relationship of LAI variation with forest type and stand characters has been seldom reported. In this study, forest type, stem number, crown coverage, proportion of evergreen conifer species to total stand BA, and proportion of deciduous species to total stand
BA and forest type were the factors significantly affecting LAI variation in January. As January is mainly the leaf senescence period of deciduous species, LAI values in January decreased with stem number and decreased with deciduous species ratio. The relationship between LAI value and the evergreen species ratio was generally the reverse of that between LAI and the deciduous species ratio. The fact that LAI values in January decreased with increasing crown coverage when crown coverage was larger than $\sim 200 \mathrm{~m}^{2}$ could be explained by large crown coverage resulting in more defoliation (in particular for deciduous species) in the forest in January (Fig. 3). The proportion of deciduous species to total stand BA significantly affected LAI variations in January and July, and the relationship between LAI and the deciduous species proportion was reversed when the ratio was smaller than 0.7 in these two seasons, which is consistent with the growth law of deciduous species. Thus, deciduous species play an important role in LAI variations across seasons. Also, the seasons have a significant effect on LAI variation by affecting leaf growth. The partial effects of stem number and crown coverage on the LAI values observed in January showed that these smooth functions were large at both ends of the $95 \%$ confidence interval. This was due to the small sample number in this range, and most were concentrated in the middle parts, the same as the partial effects of stem number on the LAI values observed in January (Figs. 3, 4).

Although the factors selected by regression could explain a small proportion ( $4 \%$ ) of spatial heterogeneity of LAI measured in July, the factors selected in January could explain $35 \%$ of the LAI spatial heterogeneity (Table 4). The LAI heterogeneity also could be affected by several other factors, such as the topography (Naithani et al., 2012), soil feature (Choler et al., 2010), soil temperature (Vitasse et al., 2009; Hardwick et al., 2015), microclimate, human activity, and other physicochemical properties. However, full leaf expansion of all tree species, which covers up the effect of other physicochemical properties on LAI, leads to a small difference in LAI in July. The effects of environmental factors (e.g. temperate and rainfall) on LAI in the forests at the fine scale should be taken into account in future studies.

Spatial heterogeneity of LAI in the three forests can yield some useful information for sampling strategy to accurately estimate of LAI using indirect measurement. An optimal sampling strategy should consider appropriate sampling plot size and the lowest sampling number that, as far as possible, obtains a high sampling accuracy and a low sampling error (Bequet et al., 2012). Our study found that strong spatial autocorrelations range were $\sim 13-27 \mathrm{~m}$ (the minimal range was $13.80 \mathrm{~m}$, and the maximal range was $27.00 \mathrm{~m}$ ) (Table 3), indicating that the range from 13 to $27 \mathrm{~m}$ might serve as the reference for sampling plot size to estimate LAI in subtropical forests. In addition, LAI heterogeneity was closely related to floristic composition and stand characters; thus stand structural variables (BA or DBH) are important for sampling strategy to measure LAI in forests (Bequet et al., 2012). 


\section{Conclusions}

This study measured LAI in three subtropical forests using a hemispherical photography method over four seasons, and offered reliable data to analyse spatial and seasonal variations in LAI. Our results indicated that LAI differed greatly with forest type and measurement season. Seasonal variation in LAI across the three forests reflects defoliation due to plant phenology. LAI values for all three forests exhibited different spatial autocorrelation in the four seasons. A clear patch distribution pattern in LAI value was found during the nongrowing seasons and this pattern gradually dwindled in the growing seasons. While stem number, crown coverage, proportion of evergreen conifer species to total stand $\mathrm{BA}$, the proportion of deciduous species to total stand BA, and forest type significantly affected spatial variations in LAI values in January, stem number and proportion of deciduous species to total stand BA significantly affected spatial variations in LAI values in July. These findings supplement LAI data for global synthesis and will provide valuable information for sampling strategies to enable more accurate estimates of LAI for simulated models of production and hydrological cycles in subtropical forests.

\section{The Supplement related to this article is available online at doi:10.5194/bg-13-3819-2016-supplement.}

Acknowledgements. This study was supported by the Specialized Research Fund for the Doctoral Program of Higher Education (20124321110006), the National Natural Science Foundation of China (31570447 and 31300524), the Programme of State Forestry Special Fund for Public Welfare Sectors of China (201304317), and the New Century Excellent Talents Program (NCET-06-0715). Thanks also go to the staff of the administration office of Dashanchong Forest Farm, Changsha County, Hunan Province, for their local support.

Edited by: A. Ito

\section{References}

Alonzo, M., Bookhagen, B., McFadden, J. P., Sun, A., and Roberts, D. A.: Mapping urban forest leaf area index with airborne lidar using penetration metrics and allometry, Remote Sens. Environ., 162, 141-153, 2015.

Aragão, L. E., Shimabukuro, Y. E., Santo, F., and Williams, M.: Landscape pattern and spatial variability of leaf area index in Eastern Amazonia, Forest Ecol. Manag., 211, 240-256, 2005.

Asner, G. P., Scurlock, J. M. O., and Hicke, J. A.: Global synthesis of leaf area index observations: implications for ecological and remote sensing studies, Global Ecol. Biogeogr., 12, 191-205, 2003.
Aston, A. R.: Rainfall interception by eight small trees, J. Hydrol., 42, 383-396, 1979.

Austin, M. P.: Spatial prediction of species distribution: an interface between ecological theory and statistical modelling, Ecol. Model., 157, 101-118, 2002.

Bequet, R., Campioli, M., Kint, V., Muys, B., Bogaert, J., and Ceulemans, R.: Spatial variability of leaf area index in homogeneous forests relates to local variation in tree characteristics, Forest Sci., 58, 633-640, 2012.

Biudes, M. S., Machado, N. G., Danelichen, V. H. M., Souza, M. C., Vourlitis, G. L., and Nogueira, J. S.: Ground and remote sensingbased measurements of leaf area index in a transitional forest and seasonal flooded forest in Brazil, Int. J. Biometeorol., 58, 11811193, 2014.

Bivand, R. S., Pebesma, E. J., and Gómez-Rubio, V.: Applied spatial data analysis with R, Springer, New York, USA, 2013.

Bréda, N. J. J.: Ground-based measurements of leaf area index: a review of methods, instruments and current controversies, J. Exp. Bot., 54, 2403-2417, 2003.

Breshears, D. D. and Barnes, F. J.: Interrelationships between plant functional types and soil moisture heterogeneity for semiarid landscapes within the grassland/forest continuum: a unified conceptual model, Landscape Ecol., 14, 465-478, 1999.

Brooks, J. R., Meinzer, F. C., Warren, J. M., Domeo, J. C., and Coulombe, R.: Hydraulic redistribution in a Douglas-fir forest: lessons from system manipulation, Plant Cell Environ., 29, 138150, 2006.

Brut, A., Rüdiger, C., Lafont, S., Roujean, J.-L., Calvet, J.-C., Jarlan, L., Gibelin, A.-L., Albergel, C., Le Moigne, P., Soussana, J.-F., Klumpp, K., Guyon, D., Wigneron, J.-P., and Ceschia, E. Modelling LAI at a regional scale with ISBA-A-gs: comparison with satellite-derived LAI over southwestern France, Biogeosciences, 6, 1389-1404, doi:10.5194/bg-6-1389-2009, 2009.

Chen, J. M.: Optically-based methods for measuring seasonal variation of leaf area index in boreal conifer stands, Agr. Forest Meteorol., 80, 135-163, 1996.

Chen, J. M., Rich, P. M., Gower, S. T., Norman, J. M., and Plummer, S.: Leaf area index of boreal forests: theory, techniques, and measurements, J. Geophys. Res., 102, 29429-29443, 1997.

Choler, P., Sea, W., Briggs, P., Raupach, M., and Leuning, R.: A simple ecohydrological model captures essentials of seasonal leaf dynamics in semi-arid tropical grasslands, Biogeosciences, 7, 907-920, doi:10.5194/bg-7-907-2010, 2010

Chiang, L. H., Pell, R. J., and Seasholtz, M. B.: Exploring process data with the use of robust outlier detection algorithms, J. Process Contr., 13, 437-449, 2003.

Clark, D. B., Olivas, P. C., Oberbauer, S. F., Clark, D. A., and Ryan, M. G.: First direct landscape-scale measurement of tropical rain forest leaf area index: a key driver of global primary productivity, Ecol. Lett., 11, 163-172, 2008.

Clark, M.: Generalized additive models: getting started with additive models in R, Center for Social Research, University of North Dame, Notre Dame, IN, USA, 31 pp., 2013.

Crockford, R. H. and Richardson, D. P.: Partitioning of rainfall into throughfall, stemflow and interception: effect of forest type, ground cover and climate, Hydrol. Process., 14, 2903-2920, 2000.

Coops, N. C., Smith, M. L., Jacobsen, K. L., Martin, M., and Ollinger, S.: Estimation of plant and leaf area index using three 
techniques in a mature native eucalypt canopy, Austral Ecol., 29, 332-341, 2004.

Dai, F. Q., Zhou, Q. G., Lv, Z. Q., Wang, X. M., and Liu, G. C.: Spatial prediction of soil organic matter content integrating artificial neural network and ordinary kriging in Tibetan Plateau, Ecol. Indic., 45, 184-194, 2014.

Demarez, V., Duthoit, S., Baret, F., Weiss, M., and Dedieu, G.: Estimation of leaf area and clumping indexes of crops with hemispherical photographs, Agr. Forest Meteorol., 148, 644-655, 2008.

Dong, X. H., Bennion, H. E., Maberly, S. C., Sayer, C. D., Simpson, G. L., and Battarbee, R. W.: Nutrients exert a stronger control than climate on recent diatiom communities in Esthwaite Water: Evidence from monitoring and palaeolimnological records, Freshwater Biol., 57, 2044-2056, 2012.

Dovey, S. B. and Toit, B. D.: Calibration of LAI-2000 canopy analyser with leaf area index in a young eucalypt stand, Trees, 20, 273-277, 2006.

Duffera, M., White, J. G., and Weisz, R.: Spatial variability of Southeastern U. S. Coastal Plain soil physical properties: implication for site-specific management, Geoderma, 137, 327-339, 2007.

Ewers, B. E. and Pendall, E.: Spatial patterns in leaf area and plant functional type cover across chronosequences of sagebrush ecosystems, Plant Ecol., 194, 67-83, 2007.

Elbasiouny, H., Abowaly, M., Abu_Alkheir, A., and Gad, A. A.: Spatial variation of soil carbon and nitrogen pools by using ordinary Kriging method in an area of north Nile Delta, Egypt, Catena, 113, 70-78, 2014.

Facchi, A., Baroni, G., Boschetti, M., and Gandolfi, C.: Comparing optical and direct methods for leaf area index determination in a maize crop, J. Agr. Eng., 1, 27-34, 2010.

Global Climate Observing System (GCOS): Systematic Observation Requirements for Satellite-Based Products for Climate Supplemental details to the satellite-based component of the Implementation Plan for the Global Observing System for Climate in Support of the UNFCCC (2010 Update), WMO/TD: 138, http: //www.wmo.int/pages/prog/gcos/Publications/gcos-154.pdf (last access: 13 November 2012), 2006

Gonsamo, A. and Chen, J. M.: Continuous observation of leaf area index at Fluxnet - Cananda sites, Agr. Forest Meteorol., 189, 168-174, 2014.

Guisan, A., Edwards Jr., T. C., and Hastie, T.: Generalized linear and generalized additive model in studies of species distributions: Setting the scene, Ecol. Model., 157, 89-100, 2002.

Guo, J., Yu, L. H., Fang, X., Xiang, W. H., Deng, X. W., and Lu, X.: Litter production and turnover in four types of subtropical forests in China, Acta Ecol. Sinica, 35, 4668-4677, 2015 (in Chinese with English abstract)

Hardwick, S. R., Toumi, R., Pfeifer, M., Turner, E. C., Nilus, R., and Ewers, R. M.: The relationship between leaf area index and microclimate in tropical forest and oil palm plantation: Forest disturbance drives changes in microclimate, Agr. Forest Meteorol., 201, 187-195, 2015.

Huang, D., Knyazikhin, Y., Wang, W., Deering, D. W., Stenberg, P., Shabanov, N., Tan, B., and Myneni, R. B.: Stochastic transport theory for investigating the three-dimensional canopy structure from space measurements, Remote Sens. Environ., 112, 35-50, 2008.
Huang, M. and Ji, J. J.: The spatio-temporal distribution of LAI in China-the comparison with mechanism model and remote sensing inversion, Acta Ecol. Sinica, 30, 3057-3064, 2010 (in Chinese with English abstract).

Iio, A., Hikosaka, K., Anten, N. P. R., Nakagawa, Y., and Ito, A.: Global dependence of field-observed leaf area index in woody species on climate: a systematic review, Global Ecol. Biogeogr. 23, 274-285, 2014.

IUSS Working Group WRB: World Reference Base for Soil Resource 2006, in: World Soil Resources Reports No. 103, 2nd Edn., FAO, Rome, 2006.

James, G., Witten, D., Hastie, T., and Tibshirani, R.: An introduction to statistical learning with applications in R, Springer, New York, 2013.

Kross, A., McNairn, H., Lapen, D., Sunohara, M., and Champagne, C.: Assessment of RapidEYE vegetation indices for estimation of leaf area index and biomass in corn and soybean crops, Int. J. Appl. Earth Obs., 34, 235-248, 2015.

Lang, A. R. G. and Xiang, Y.: Estimation of leaf area index from transmission of direct sunlight in discontinuous canopies, Agr. Forest Meteorol., 35, 229-243, 1986.

Lee, K. S., Cohen, W. B., Kennedy, R. E., Maiersperger, T. K., and Gower, S. T.: Hyperspectral versus multispectral data for estimating leaf area index in four different biomes, Remote Sens. Environ., 91, 508-520, 2004.

Lei, X. D., Wang, W. F., and Peng, C. H.: Relationships between stand growth and structural diversity in spruce-dominated forests in New Brunswick, Canada, Can. J. Forest Res., 39, 1835-1847, 2009.

Liu, X. L., Zhao, K. L., Xu, J. M., Zhang, M. H., Si, B., and Wang, F.: Spatial variability of soil organic matter and nutrients in paddy fields at various scales in southeast China, Environ. Geol., 53, 1139-1147, 2008.

Liu, Y. B., Ju, W. M., Chen, J. M., Zhu G. L., Xing, B. L., Zhu, J. F., and He, M. Z.: Spatial and temporal variations of forest LAI in China during 2000-2010, Chinese Sci. Bull., 57, 2846-2856, 2012.

Liu, Z. L., Jin, G. Z., Chen, J. M., and Qi, Y. J.: Evaluating optical measurements of leaf area index against litter collection in a mixed broadleaved-Korean pine forest in China, Trees, 29, 5973, 2015a.

Liu, Z. L., Wang, C. K., Chen, J. M., Wang X. C., and Jin, G. Z.: Empirical models for tracing seasonal changes in leaf area index in deciduous broadleaf forests by digital hemispherical photography, Forest Ecol. Manag., 351, 67-77, 2015b.

Lopes, D., Nunes, L., Walford, N., Aranha, J., Sette Jr., C., Viana, H., and Hernandez, C.: A simplified methodology for the correction of Leaf Area Index (LAI) measurements obtained by ceptometer with reference to Pinus Portuguese forests, iForestBiogeosci. Forest., 7, 186-192, 2015.

Lopez-Granados, F., Jurado-Exposito, M., Alamo, S., and GarciaTorres, L.: Leaf nutrient spatial variability and site-specific fertilization maps within olive (Olea europaea L.) orchards, Eur. J. Agron., 21, 209-222, 2004.

Macfarlane, C., Hoffman, M., Eamus, D., Kerp, N., Higginson, S., McMurtrie, R., and Adams, M.: Estimation of leaf area index in eucalypt forest using digital photography, Agr. Forest Meteorol., 143, 176-188, 2007. 
Manninen, T., Korhonen, L., Voipio, P., Lahtinen, P., and Stenberg, P.: Leaf area index (LAI) estimation of boreal forest using wide potics airborne winter photos, Remote Sens., 1, 1380-1394, 2009.

Mason, P. J., Manton, M., Harrison, D. E., Belward, A., Thomas, A. R., and Dawson, A.: The second report on the adequacy of the global observing systems for climate in support of the UNFCCC. GCOS-82, WMO/TD No. 1143, United Nations Environment Programme, International Council for Science, World Meteorological Organization: Geneva, Switzerland, 2003, p. 74, 2003

Mcdowell, N. G., Adams, H. D., Bailey, J. D., and Kolb, T. E.: The role of stand density on growth efficiency, leaf area index, and resin flow in southwestern ponderosa pine forests, Can. J. Forest Res., 37, 343-355, 2007.

Myneni, R. B., Hoffman, S., Knyazikhin, Y., Privette, J. L., Glassy, J., Tian, Y., Wang, Y., Song, X., Zhang, Y., Smith, G. R., Lotsch, A., Friedl, M., Morisette, J. T., Votava, P., Nemani, R. R., and Running, S. W.: Global products of vegetation leaf area and fraction absorbed PAR from year one of MODIS data, Remote Sens. Environ., 83, 214-231, 2002.

Naithani, K. J., Ewers, B. E., and Pendall, E.: Sap flux-scaled transpiration and stomatal conductance response to soil and atmospheric drought in a semi-arid sagebrush ecosystem, J. Hydrol., 25, 176-185, 2012.

Naithani, K. J., Baldwin, D. C., Gaines, K. P., Lin, H., and Eissenstat, D. M.: Spatial distribution of tree species governs the spatio-temporal interaction of leaf area index and soil moisture across a forested landscape, PLoS One, 8, e58704, doi:10.1371/journal.pone.0058704, 2013.

Niinemets, Ü.: A review of light interception in plant stands from leaf to canopy in different plant functional types and in species with varying shade tolerance, Ecol. Res., 25, 693-714, 2010.

Ouyang, S., Xiang, W. H., Wang, X. P., Zeng, Y. L., Lei, P. F., Deng, X. W., and Peng, C. H.: Significant effects of biodiversity on forest biomass during the succession of subtropical forest in south China, Forest Ecol. Manag., 372, 291-302, 2016.

R Development Core Team: R: A language and environment for statistical computing, R Foundation for Statistical Computing, Vienna, Austria, 2015.

Rich, P. M.: Characterizing plant canopies with hemispherical photographs, Remote Sens. Rev., 5, 13-29, 1990.

Richardson, J., Moskal, L. M., and Kim H.: Modeling approaches to estimate effective leaf area index from aerial discrete-return LIDAR, Agr. Forest Meteorol., 149, 1152-1160, 2009.

Rossi, R. E., Mulla, D. J., Journel, Á. G., and Franz, E. H.: Geostatistical tools for modeling and interpreting ecological spatial dependence, Ecol. Monogr., 62, 277-314, 1992.

Ryu, Y., Nilson, T., Kobayashi, H., Sonnentag, O., Law, B. E., and Baldocchi, D. D.: On the correct estimation of effective leaf area index: dose it reveal information on clumping effects, Agr. Forest Meteorol., 150, 463-472, 2010.
Shao, P. and Zeng, X. D.: Spatiotemporal relationship of leaf area index simulated by CLM3.0-DGVM and climatic factors, Acta Ecol. Sinica, 16, 4725-4731, 2011 (in Chinese with English abstract).

Shen, C. C., Lei, X. D., Liu, H. Y., Wang, L., and Liang, W. J.: Potential impacts of regional climate change on site productivity of Larix olgensis plantations in northeast China, iForest-Biogeosci. Forest., 8, 642-651, 2015.

Smith, H.: Light quality as an ecological factor, in: Plants under their atmospheric environment, edited by: Grace, J., Ford, E. D., and Jarvis, P. G., Blackwell, Oxford, 93-110, 1981.

Sprintsin, M., Karnieli, A., Berliner, P., Rotenberg, E., Yakir, D., and Cohen, S.: The effect of spatial resolution on the accuracy of leaf area index estimation for a forest planted in the desert transition zone, Remote Sens. Environ., 109, 416-428, 2007.

Tian, Y., Dickinson, R. E., Zhou, L., Zeng, X., Dai, Y., Myneni, R. B., Knyazikhin, Y., Zhang, X., Friedl, M., Yu, H., Wu, W., and Shaikh, M.: Comparison of seasonal and spatial variations of leaf area index and fraction of absorbed photosynthetically active radiation from moderate resolution imaging spectroradiometer (MODIS) and common land model, J. Geophys. Res, 109, 19-34, 2004.

Tobin, B., Black, K., Osborne, B., Reidy, B., Bolger, T., and Nieuwenhuis, M.: Assessment of allometric algorithms for estimating leaf biomass, leaf area index and litter fall in differentaged Sitka spruce forests, Forestry, 79, 453-465, 2006.

Vitasse, Y., Delzon, S., Dufrêne, E., Pontailler, J. Y., Louvet, J. M., Kremer, A., and Michalet, R.: Leaf phenology sensitivity to temperature in European trees: do within-species populations exhibit similar responses, Agr. Forest Meteorol., 149, 735-744, 2009.

Wood, S.: Generalized Additive Models: An introduction with R, Chapman \& Hall, CRC, Boca Raton, FL, USA, 8-15, 2006.

Woodgate, W., Jones, S. D., Suarez, L., Hill, M. J., Armston, J. D., Wilkes, P., Soto-Berelov, M., Haywood, A., and Mellor, A.: Understanding the variability in ground-based methods for retrieving canopy openness, gap fraction, and leaf area index in diverse forest systems, Agr. Forest Meteorol., 205, 83-95, 2015.

Xiang, W., Fan, G., Lei, P., Zeng, Y., Tong, J., Fang, X., Deng, X., and Peng, C.: Fine root interactions in subtropical mixed forests in China depend on tree species composition, Plant Soil, 395, 335-349, 2015.

Xiang, W. H., Hou, Y. N., Ouyang, S., Zhang, S. L., Lei, P. F., and Li, J. X.: Development of allometric equations for estimating tree component biomass of seven subtropical species in southern China, Eur. J. For. Res., in review, 2016.

Yao, D. D., Lei, X. D., Yu, L., Lu, J., Fu, L. Y., and Yu, R. G.: Spatial heterogeneity of leaf area index of mixed spruce-fir-deciduous stands in northeast China, Acta Ecol. Sinica, 1, 71-79, 2015 (in Chinese with English abstract). 